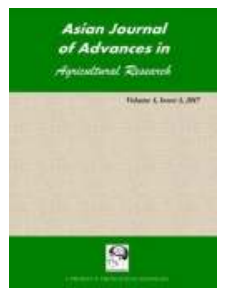

\title{
Unfolding History of Local Guinea Sorghum Enhanced for Food Quality through Potassium Hydroxide and Bleach Test: Farmer Alternative to Climate Variability Resilience
}

\author{
Teme Niaba $^{{ }^{\star}}$, Traoré Karim ${ }^{2}$, Kouressy Mamoutou ${ }^{1}$, Sidibé Salimata ${ }^{1}$, \\ Traoré Kalifa ${ }^{1}$, Niangado Oumar ${ }^{3}$, B. Coulibaly Sidi ${ }^{1}$, Dembélé Bourema ${ }^{1}$, \\ Coulibaly Mamadou ${ }^{1}$, Vaksmann Michel ${ }^{4}$, Diallo Abdoulaye Gaoussou', \\ Traoré Kissima ${ }^{1}$, Touré Abocar Omar ${ }^{1}$, NDiaye Mamadou ${ }^{1}$, Touré Aboubacar ${ }^{5}$, \\ Boubacar Aly ${ }^{1}$ and Diourté Mamourou ${ }^{1}$ \\ ${ }^{1}$ Institut d'Economie Rurale (IER), BP 258, Rue Mohamed V, Bamako, Mali. \\ ${ }^{2}$ Africa Rice Center, St. Louis, BP 96, Sénégal. \\ ${ }^{3}$ Delegation Fondation Syngenta Pour Une Agriculture Durable, Bamako, Mali. \\ ${ }^{4}$ CIRAD/IER, BP 3299, Bamako, Mali. \\ ${ }^{5}$ ICRISAT, BP 320, Mali.
}

Authors' contributions

This work was carried out in collaboration between all authors. Author TN designed the study, performed the statistical analysis, wrote the protocol and the first draft of the manuscript.

Authors Traore Karim and TA improved data quality analysis and the manuscript. Authors Traore Kalifa and DB improved the first draft. Author VM drew the map and improved the manuscript. Author

SS performed testa, to laboratory works and improved the manuscript. Author Traore Kissima participated in field work, data collection and analysis. Authors NO, BA, DAG, TAO, CM, DM and KM

participated in the diffusion and document improvement. All authors read and approved the final manuscript.

Article Information

DOI: 10.9734/AJAAR/2017/35133

Editor(s):

(1) Sharad Kumar Dwivedi, ICAR-Research Complex for Eastern Region, Patna, Bihar, India.

Reviewers:

(1) Khalifa Muhammad Aljameel, Usmanu Danfodiyo University ,Sokoto, Nigeria.

(2) Moses Owuor Oyier, Egerton University, Kenya. Complete Peer review History: http://www.sciencedomain.org/review-history/20280

Original Research Article

Received $29^{\text {th }}$ June 2017

Accepted $25^{\text {th }}$ July 2017

Published $29^{\text {th }}$ July 2017

*Corresponding author: Email: niabateme@gmail.com; 


\section{ABSTRACT}

Sorghum (Sorghum bicolor (L). Moench) is an important staple food crop produced essentially under rained conditions in Mali. To preserve and exploit sorghum genetic diversity, germplasm collection was undertaken in 1978 across Mali. During this germplasm evaluation in 1982, a particular guinea sorghum cultivar from Chegue village in north western Mali, recorded as CSM63, was identified for its earliness and photoperiod insensitivity. This cultivar was unfortunately segregating not only for a testa presence, which is detrimental to Tô color and nutritional quality, but also for flowering time and plant height. Field screening coupled with the potassium hydroxide and bleach $(\mathrm{KOH}: \mathrm{B})$ tests were performed to eliminate testa while maintaining CSM63 agronomic values. Overall objectives were to trace history of CSM63 native population, screen for testa absence and define its favorable cropping zone. Field experiments were conducted at the Cinzana Agronomic Research Station (SRAC) while laboratory tests for testa absence and cooking quality were conducted at Sotuba Food Technology Laboratory (LTA) in Mali. Two thousand (2000) plants from original CSM63 population were grown in a complete isolation from other sorghum varieties to select 288 panicles for testa absence. For yield trial, a completely randomized block design was used with 3 replications. After series of selfing, a pure new line (CSM63-18-1AF) was identified without a testa with similar maturity, grain yield, better Tô color and nutritional values than the original CSM63. The new line was named CSM63E and its cropping zones were delimited beyond its center of origin. CSM63E was released for large scale production by Institut d'Economie Rurale (IER) and registered in National and West African Countries Regional Sorghum Catalogs. The adopted line is named Jakunbe (prevent drought) in Bambara language) by farmers. Jakunbe is the number one certified sorghum seed produced in Mali in 2016 in term of quantity. Cropping both Jakunbe and late maturing varieties beyond isohyets $700 \mathrm{~mm}$ exposes farmers to yield losses caused by non-proper environment.

Keywords: Sorghum; testa; germplasm; nutritional values; prevent drought.

\section{INTRODUCTION}

Sorghum (Sorghum bicolor (L.) Moench) is a main staple cereal crop in Mali along with millet, rice and maize. Sorghum is cultivated in rain-fed conditions, or in river receding conditions in the northern regions. In 2016, Malian sorghum production accounted for 1637912 t ranking fourth in term of production behind rice (Oriza sativa) (2 811049 t), maize (Zea mays) (2 533 $999 \mathrm{t}$ ) and millet (Pennisetum glaucum) (1 927 $106 \mathrm{t})$. Sorghum stayed in the same position in 2015 with $1527456 \mathrm{t}$, following the same ranking [1]. Among the five cultivated races of sorghum, the guinea race composed of the guineense and margaritiferum working groups, accounts for more than $70 \%$ of sorghum cultivated in West and Central Africa and may account for more than $50 \%$ of the all sorghum produced in Africa [2]. Guinea race dominates southern, central and Northern Mali zones in areas and production. There is a large maturity variability within this race following south- north rainfall gradient.

Most sorghums grown by farmers are local or improved guinea cultivars very well adapted to the local environments rather than introductions or improved sorghums without guinea background. Consumers prefer the cooking traits of guinea sorghums and their derivatives excluding those with a testa. Testa occurrence is under genetic control and poor seed renewal from farmers.

Testa is maternally inherited. The genetic constitution of the testa, aleurone and embryo are: testa is a diploid and derives entirely from maternal tissue. Aleurone is triploid with one sperm of the male combining with the two polar bodies of the female, and the embryo is a diploid, receiving one genome from each parent. After the double fertilization (formation of the embryo (2n) and endosperm (3n), unfertilized diploid cells from the ovule divide mitotically to form part of the seed coat (testa) which is not affected by paternal genes $[3,4,5]$.

Genetically, two dominant genes $\left(B_{1} B_{2}\right)$ control the presence or absence of testa. If either $B_{1}$ or $\mathrm{B}_{2}$ are homozygous recessive, the testa cells either disintegrate and are absorbed or do not develop. When the genes controlling the testa, $\mathrm{B}_{1}$ and $\mathrm{B}_{2}$, and the spreader, $\mathrm{S}$, are dominant, tannins from the testa will diffuse into the pericarp. When $S$ is recessive with dominant $B_{1}$ (most guinea types) and $\mathrm{B}_{2}$ (USA germplasm types), tannins reside only in the testa layer $[6,7]$. 
When $\mathrm{B}_{1} \mathrm{~B}_{2}$ are dominant, a pigmented testa is present. When either or both genes are homozygous recessive $\left(B_{1} B_{2}, \quad b_{1} b_{1} B_{2}\right.$, or $\left.b_{1} b_{1} b_{2} b_{2}\right)$ pigmentation is absent. The color of the pigmented testa is controlled by another gene (Tp) in which brown is dominant to purple. The spreader gene (S) allows the brown color of a pigmented testa to be present in the epicarp (S-). Authors [7] argued that several genes are involved in pigmentation control and pericarp thickness: When mesocarp is thin, $Z$ gene is dominant (Z-) and thick when the gene is recessive ( $z z)$. $R, Y, I, B_{1} B_{2}$, and $S$ genes are associated with the presence of phenolic compounds that could be antifungal, conferring grain mold resistance, while thin mesocarp, determined by the amount of starch granules present, is also thought to confer grain mold resistance. These mold resistance phenolic compounds are present in some guinea sorghum varieties, thus conferring them poor purple Tô color not well culturally appreciated by consumers $[7,8]$.

Pericarp color (white, red, yellow) depends on thickness of the seed coat and presence or absence of the testa. Three genes ( $\left.R_{-} Y_{-} Z_{-}\right)$ control the color and intensity of the pericarp and variation in the appearance of the testa [6]. Authors [7] claimed that seven loci are known to be responsible for the different characteristics affecting caryopsis traits (grain): R, Y, I, Z, B1, $B 2$, and $S$ genes. The $R$ and $Y$ genes determine pericarp color. If both genes are dominant $(R-Y)$, then the pericarp is red. When the $Y$ gene in homozygous recessive (R-yy or rryy), the pericarp is colorless or white regardless of the $R$ gene. A lemon-yellow pericarp is found when the $R$ gene is homozygous recessive and the $Y$ gene is dominant (rrY-). The intensifier gene (I) modifies the color of the pericarp to appear bright when dominant (I-) and dull when recessive (ii).

Testa [9] affects adversely nutritional quality of sorghum grain. Studies in rats, chicks and livestock have shown that high tannin in the diet adversely affects digestibility of protein and carbohydrates and reduces growth, feeding efficiency, metabolizable energy and bioavailability of amino acids. There is no direct evidence regarding anti-nutritional effects of dietary tannins in human subjects, although high dietary tannin may have some carcinogenic effect. Iron absorption in Indian women was lower when they were fed porridge prepared from bird-resistant high-tannin sorghum in place of porridge prepared from tannin-negative sorghum [10]. In a study elucidating the relationship of the testa to agronomic and nutritional traits in sorghum, [11] reported that among the nutritional and mineral traits the testa types had more protein, lysine percent sample, potassium, and tannin; and less lysine percent protein, oil, carbohydrate, phosphorus, gross energy, enzyme ( $\alpha$-amylase) activity, in vitro dry matter digestibility, and metabolizable energy than the non-testa types. However, the results were highly influenced by environment. They concluded that sorghums with testa were inferior nutritionally to non-testa ones and tended to be inferior agronomically. The only advantage of the testa was higher protein and lysine percent sample [9].

Tannin from sorghum was advocated as having strong antioxidant activity $[12,13]$. These authors $[12,13]$ found that tannin sorghums had antioxidant activities higher than most non-tannin sorghums. Meantime [12,14] argued that high molecular weight (MW) tannins have the greatest antioxidant activity in vitro among natural antioxidants. This was attributed to the proximity of many aromatic rings and hydroxyl groups and the fact that tannins were not able to act as prooxidants [12]. A major concern about tannins though is that they may not be biologically effective antioxidants due to their large molecular size and their tendency to bind food molecules into insoluble complexes. However, [13] demonstrated that even when complexed with proteins, sorghum tannins retained at least $50 \%$ of their antioxidant activity. Such proteincomplexed tannins may serve as free radical sinks in the digestive system thus sparing other antioxidants.

Traditional methods to inactivate and detoxify tannins include moisturizing the grain with alkali several hours prior to utilization, formaldehyde, polyethylene and glycol and gelatin treatments [10]. Another method of determining condensed tannins in sorghum is the vanillin- $\mathrm{HCl}$ method when the blanks are subtracted to eliminate background non-tannin materials. However, it requires significant time and is not readily applied in routine grading of sorghum [15].

Grain hardness is the most important and consistent grain characteristic that affects Tô quality [16]. Sorghums with corneous (hard) endosperm generally produce good quality Tô whereas very hard like "kende" margariteferum type and very soft endosperm like "Gadiaba" durra type sorghums produce poor quality Tô [17]. Authors [17] claimed that Tô of poor quality resulted from fine flour particles $(<250 \mu \mathrm{m})$ while medium size flour particles $(<425 \mu \mathrm{m})$ produced 
intermediate sorghum Tô quality. Guinea sorghums, including CSM63, have hard and corneous grain predisposing them to good Tô quality.

CSM63 was identified for its early maturing among guinea race cultivars in the 1984 preliminary agronomic trait evaluation of the 1978 Malian sorghum germplasm collection [18]. The collections were aimed at preserving Malian germplams from genetic erosion and identifying racial diversity and maturing group of cultivars in the Sahel region to secure production due to recurrent droughts. Despite its earliness, CSM63 showed limited food and market values due to its testa and high tannin content by consumers. Different types of foods, including Tô and couscous from guinea sorghums, constitute the major daily food sources consumed by most rural and low income urban Malians. However, in Tominian, Koutiala and Bandiagara districts of Mali, tannin content sorghum grains are well preferred by women for local beer.

The objectives of this study were to: (1) screen CSM63 for the absence of testa, (2) identify nontesta CSM63 derivatives for agronomic and cooking qualities and (3) define its optimal cropping area.

Thus, the need for improving the cooking quality of CSM63 by eliminating the testa while maintaining its original agronomic values was imperative for Tô, Malian traditional food. Pure line selection (PLS) (single plant selection from a segregating landrace variety population with progeny testing) in addition to the potassium hydroxide $(\mathrm{KOH})$ and bleach $(\mathrm{B})$ test were used to improve CSM63.

\section{MATERIALS AND METHODS}

\subsection{Plant Material}

A team composed of IER and CIRAD scientists collected CSM63 (PI8939) in 1978 [18]. CSM63 local name is Keninke from Chegue village in Nara District (37 km from Mauritania). Chegue is located in longitude $06^{\circ} .57^{\prime}$ West and latitude $15^{\circ} .11^{\prime}$ North. Farmers indicated that CSM63 matures in 90 days. The original CSM63 segregates for plant height, maturity, pericarp thickness, glumes color and testa.

Plant material was composed of original CSM63 population, selected derived pure lines from original CSM63, CSM219E, CSM417E and Framida as checks.

\subsection{Methodology}

\subsubsection{Field screening}

Approximately $1 / 14$ of a hectare was planted in 1986-1987 cropping season with the CSM63 original population in a complete isolation from other sorghum fields at the Cinzana Agronomic Research Station (SRAC) in well 10 (F10). The final population was 2000 plants. Two hundred and eighty-eight (288) selfed panicles were retained for testa absence at maturity. Seed from 288 panicles were planted along with bulk seeds of the original population at the SRAC to determine flowering and testa absence in 19871988 cropping season. Ten panicles in each progeny row, except those from the original population, were selfed per plot before flowering. Forty-five lines (45) from 15 families were visually selected for testa absence and planted in 1989-1990 season at SRAC for flowering, testa absence, plant height, maturity and flour quality. A field test for testa presence was performed by scraping 10-20 seeds per panicle with pocket knife and by flour appreciation before the $\mathrm{KOH}$ : B test on 45 families.

\subsubsection{Agronomic vield test}

For testa screening experiment, one row observation plot of $5 \mathrm{~m}$ was used per entry from 1987 to 1989.

For yield test of 1990-1991, randomized complete block design (RCBD) was used with three replications. Experimental unit was three rows per entry. Spacing between rows was 0.75 $\mathrm{m}$ and $0.50 \mathrm{~m}$ between hills on the row for preliminary and yield tests. Row length was $5 \mathrm{~m}$ long. Net plot length was $4.5 \mathrm{~m}$ (9 hills $/ \mathrm{row}$ ) with an expected 27 hills at harvest by plot for grain yield. Planting was done on 19/07/1991. Thinning was performed at two plants per hill with a population density of 53333 plants per hectare. Experiments were under rain-fed conditions. Hundred $(100 \mathrm{~kg} / \mathrm{ha})$ of diammonium phosphate $\left(\mathrm{DAP}=18 \mathrm{~N}-46 \mathrm{P}_{205}\right)$ were applied two weeks at thinning time and $50 \mathrm{~kg} / \mathrm{ha}$ of urea $(46 \mathrm{~N})$ were applied as side dressing 40 days after emergence. Furrows were dug alongside each ridge close to seedlings to bury fertilizers. The first weeding was done on 2 July during thinning time; the second was on 30 July and the third was on 15 September during ridging time. Harvest was achieved after physiological maturity when grains were completely dried. Panicles from each plot was dried and weighted 
twice to confirm weight stability before threshing. Threshing was done by women using mortar and pestle.

\subsubsection{Selected agronomic data}

Data on number of days to $50 \%$ flowering (FD), plant height $(\mathrm{PH})$ in $\mathrm{cm}$, number of hills harvested $(\mathrm{HH})$, number of panicles harvested (PAH), percent threshing (\%PT), panicle weight (PWT) and grain yield GY (kg/ha) were collected.

\subsubsection{Bleach, potassium hydroxide ( $\mathrm{KOH}: \mathrm{B})$ and tô cooking tests}

The bleach test method $[15,19]$ of screening sorghum samples for the presence or absence of the testa was used in this study at the Sotuba Food Technology Laboratory (LTA) in 1989 on 45 derived lines from 15 families. Fifty (50) pure lines seeds derived from original CSM63 were randomly counted twice per set plus four checks. Each sample set was immersed in a concentration of 1:5 (weight volume $(\mathrm{w} / \mathrm{v})$ of $\mathrm{KOH}: \mathrm{B})$ at a water bath temperature of $60^{\circ} \mathrm{C}$ for 15 minutes. Kernels were then rinsed, dried and separated for the presence and absence of the testa in each sample.

For the Tô cooking quality, ten (10 gr) grams of potassium hydroxide were dissolved in 2.5 liters of water to create an alkali solution in 1989. Tô was then cooked in $20 \mathrm{~g}$ of flour and $80 \mathrm{ml}$ of alkali solution. The $\mathrm{pH}$ of the solution was 11 and that of the Tô was 9 on average. Keeping (consistency) quality of Tô was measured 24 hours after cooking.

\subsubsection{Laboratory data collected}

For cooking properties, testa presence, percentage of decortication (PD), consistency of Tô in millimeter (TCmm) and manual (touching) (MTC) after 24 hours for keeping quality (overnight keeping) and Tô color (TC) were recorded.

Tô consistency after overnight keeping was measured in millimeter ( $\mathrm{mm}$ ) (using penetrometer and manually (Tô consistency commonly used by households) was scored using a scale of 1 (very good), 2 (good), 3 (soft), 4 (clammy, sticky) and 5 (very sticky). Tô color (TC) was scored on a scale of 1 (cream or white pale, good Tô color), 2 (gray to slightly maroon), 3 (maroon to dark gray), 4 (brown or light dark) and 5 (dark or dark brown, very bad TC).
Samples with a score of 3 and above are classified as unacceptable for TC but the grains can be acceptable for couscous, another Malian food, according to the Sotuba Food Technology Laboratory (LTA) standards.

\subsubsection{Data analysis}

Descriptive statistics and analyses of variance for parametric and none parametric data using MINITAB 14 software were performed. Percent decortication was not transformed because all samples had the same denominator values. Tô manual consistency, color, and conservation were analyzed using Kruskal-Wallis, $\chi^{2}$ type test for means rank separation. All significances were determined at the probability threshold of $P=0.05$.

\section{RESULTS}

\subsection{Environmental Conditions at the Experimental Site}

The Cinzana Agricultural Research Station (SRAC) is five $\mathrm{km}$ from the Cinzana village. SRAC is located in the Sahelian zone of Mali (Fig. 3) with geographic coordinates of $13^{\circ} 15^{\prime} \mathrm{N}$; $558 \mathrm{~W}$ and $265 \mathrm{~m}$ of altitude. SRAC is $45 \mathrm{~km}$ from its regional capital, Ségou. It has monomodal rainfall pattern with distinct rainy season in summer accounting on average for $690 \mathrm{~mm}$. Mean annual maximal temperature is $35.6^{\circ} \mathrm{C}$ and minimal is $19.3^{\circ} \mathrm{C}$ (Fig. 1) with a maximum day length of $12 \mathrm{~h} 47$. Maximum temperatures are recorded from April to May and the minimum from December to February. The climate is characterized by an inter-annual variability of rainfall, turbulent high intensity, and irregular intra-season rains. The soil is classified as a leached tropical ferruginous soil with spots and concretions for the Station and loamy-sand type with $\mathrm{pH}$ varying from 5.5 to 6 (slightly acid) at the experiment site.

\subsection{Field Data}

Number of different panicles retained from 2000 plants was 288 in 1986-1987, 45 from 288 plants in 1987-1988, 8 from 45 plants in 1989-1990 and 1 from 8 in 1990-1991 respectively per cycle of selection per normal cropping season. These numbers correspond respectively to selection pressure of 14,$40 ; 15,63 ; 17,78$ and $12.5 \%$ per cycle of selection for non testa presence. In 1988-1989 and 1989-1990, there were respectively observation nurseries of selected 45 and 8 panicles for flowering and plant height. 


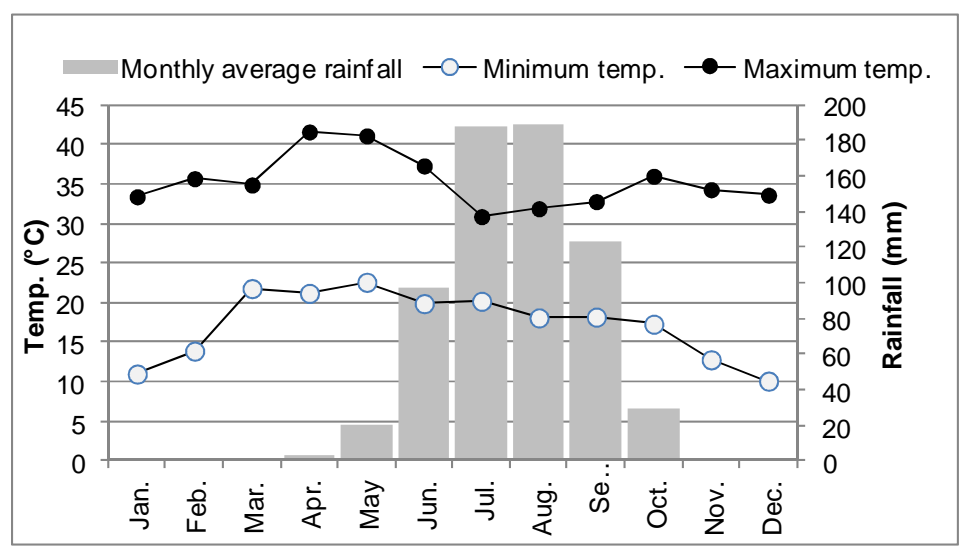

Fig. 1. Monthly average rainfalls, minimum and maximum temperatures at the experimental site from 1986-1991. Cropping season starts on average in the third decade of June and ends in late September. Maximum rainfall occurs in July and August. For mid July planting, CSM63E reaches $50 \%$ flowering early September and maturity is complete in early October; giving the opportunity for early new crop harvest, thus overcoming food shortage before new traditional crop harvest

Means $50 \%$ flowering time of the 288 panicles was 65 days with a maximum of 75 days and a minimum of 59 days. For the 45 panicles, the average $50 \%$ flowering time was 61 days with a maximum of 69 days and a minimum of 55 days. Tables 1 and 2 give respectively agronomic traits information and analysis of variance on the 8 pure lines and original CSM63 population.

Eight lines were retained (Table 1) after the $\mathrm{KOH}: \mathrm{B}$ test. There was no difference among the 9 lines for grain yield, while there were highly significant differences among lines for FD, $\mathrm{PH}$ and \% decortication. Selected agronomic and cooking qualities are shown (Tables 1, 3, 4).

\subsection{Laboratory Data}

The average percentage of testa of the 45 random individuals was $7.8 \%$, while that of the original population was $76 \%$ after $\mathrm{KOH}$ : B test (Table 4). Three lines showed no testa presence (CSM63E-13-1AF, CSM63E-13-2AFand SM63E18-1AF). Fig. 2 shows some false testa presence in CSM 219E caused by insects bites and weathering.

For the 9 lines, there were differences among treatments due to decortication (Table 1). Tô color and consistency were the same for non testa samples. Kruskal-Wallis rank test (Table 3) revealed no differences among treatments for manual Tô consistency $\left(H=8.63<\chi^{2}=14.11\right)$. Tô color was 1 for all sample tested compared to 2 for the check (Table 3). Visual evaluation of flour (data not reported) was important during the early stages of the screening at Cinzana Agronomic Research Station (SRAC).

The characteristics of the new released improved CSM63E are: early maturity (90 days from planting to physiological maturity); reduced plant height $(286 \mathrm{~cm})$; purple plant type; red glumes; thick and white pericarp; no testa; photo-period insensitive. Grain yield (1.96 t/ha) was obtained at Cinzana Agronomic Research Station (Table 1) in 1990-1991.

\subsection{CSM63E Adaptation Zone}

Currently CSM63E has been intensively grown by framers in Mali from 400 to $900 \mathrm{~mm}$ rainfall zones. Delayed planting is applied in late July for maturity to occur end of September in rainier areas $(900 \mathrm{~mm})$. Each gradient planting period was applied to delineate CSM63E optimal yield potential from $700 \mathrm{~mm}$ (Kondogola village), 900 $\mathrm{mm}$ rainfall (Kafara village) and $800 \mathrm{~mm}$ (Finkoloni village) (Fig. 3). Study on the impact of the Cinzana Agronomic Research Station indicated that CSM63E is the most cultivated improved sorghum at farm level in Ségou (81\%) $(600-700 \mathrm{~mm})$ and Mopti (99\%) (400-500 mm), regions. Large scale adoption of CSM63E was subsequent to its early maturing and grain yield (229-371 kg/ha) over local checks by farmers [20]. Malian Seed Certification Central Laboratory report of 2016-2017 cropping season data showed that CSM63E is the most produced 
certified sorghum seed among 39 varieties. Its certified see produced in 2016-2017 cropping season was $365.750 \mathrm{t}$ or $62 \%$ of the total certified sorghum seeds (589.953 t) [21].

Table 1. Selected agronomic traits of CSM63E lines from the Cinzana Agronomic Research Station 1991-1992 and Food Technology Laboratory (LTA) in 1990-1991

\begin{tabular}{|c|c|c|c|c|c|c|c|c|c|}
\hline Lines & $\begin{array}{l}50 \% \\
\text { FD- } \\
\text { days }\end{array}$ & PH-cm & PA & $\begin{array}{l}\text { PWT (kg) } \\
\text { per plot }\end{array}$ & PT & $\begin{array}{l}\text { GY } \\
\text { t/ha }\end{array}$ & GC & $\begin{array}{l}\text { \%Grain } \\
\text { décor } \\
\text { tication }\end{array}$ & \%Testa \\
\hline 1.CSM63E-13-1AF & 70 & 292 & 48 & 2.21 & 60.94 & 1.37 & black & 81.72 & 0 \\
\hline 2.CSM63E-13-2AF & 67 & 249 & 62 & 2.57 & 66.07 & 1.70 & black & 87.83 & 0 \\
\hline 3.CSM63E-17-1AF & 72 & 323 & 75 & 2.74 & 59.87 & 1.63 & black & 87.65 & 5 \\
\hline 4.CSM63E-17-2AF & 70 & 306 & 42 & 2.41 & 64.85 & 1.57 & black & 81.05 & 5 \\
\hline 5.CSM63E-18-1AF & 63 & 286 & 62 & 3.10 & 65.25 & 1.96 & red & 86.12 & 0 \\
\hline 6.CSM63E-20-1AF & 74 & 316 & 39 & 2.13 & 60.56 & 1.30 & red & 85.57 & 10 \\
\hline 7.CSM63E-20-2AF & 71 & 296 & 60 & 3.11 & 68.86 & 2.15 & black & 86.02 & 10 \\
\hline 8.CSM63E-31-1AF & 69 & 290 & 58 & 2.99 & 56.05 & 1.70 & - & 85.92 & 5 \\
\hline 9.CSM63-original & 65 & 319 & 72 & 3.34 & 65.11 & 2.18 & Black/red & 85.5 & 76 \\
\hline Mean & 69 & 297 & 57 & 2.73 & 63.06 & 1.73 & & 85.21 & \\
\hline C.V.\% & 3.45 & 6.400 & 24.720 & 21.50 & 13.74 & 28.01 & - & 0.3 & - \\
\hline $\mathrm{LSD}_{0.05}$ & 3.40 & 27.12 & - & - & - & - & - & 0.437 & - \\
\hline P. value & 0.001 & 0.006 & 0.077 & 0.199 & 0.746 & 0.329 & - & 0.000 & - \\
\hline
\end{tabular}

Table 2. Analysis of variance of agronomic traits and decortication percentage of CSM63 derived pure lines conducted at Cinzana in 1990-1991

\begin{tabular}{llllllll}
\hline \multirow{2}{*}{ Traits } & \multicolumn{2}{c}{ Mean square } & Grand mean & F-value & LSD 0.05 & C.V.\% & Pr>F \\
\cline { 2 - 6 } & Genotype & Error & & & & \\
\hline 50\% flowering & 33.231 & 5.690 & 69.074 & 4.290 & 5.840 & 3.450 & $\mathbf{0 . 0 0 4}$ \\
Plant height & 1553.750 & 361.875 & 297.444 & 4.290 & 27.118 & 6.400 & $\mathbf{0 . 0 0 6}$ \\
Panicles harvested & 459.667 & 201.653 & 57.444 & 2.280 & 20.243 & 24.72 & 0.077 \\
Hills harvested & 12.593 & 16.315 & 21.185 & 0.77 & 5.758 & 19.07 & 0.633 \\
Panicle weight & 555748.148 & 345525.926 & 2734.074 & 1.610 & 837.934 & 21.50 & 0.199 \\
Percent threshing & 46.887 & 75.084 & 63.063 & 0.620 & 12.352 & 13.74 & 0.746 \\
Grain yield kg/ha & 295631.481 & 234664.815 & 1729.259 & 1.260 & 690.548 & 28.01 & 0.329 \\
\%Decortication & 13.092 & 0.053 & 85.213 & 246.030 & 0.437 & 0.300 & $\mathbf{0 . 0 0 0}$ \\
\hline \multicolumn{7}{c}{ Probability of significance: $P=0.05$} \\
\end{tabular}

Table 3. Kruskal Wallis rank test for tô consistency and color of CSM63E of non testa pure lines conducted at the Sotuba Food Technology Laboratory (LTA), in Mali 1990-1991

\begin{tabular}{|c|c|c|c|c|c|c|}
\hline Tests & Mean & Maxi & Mini & F.V & P.V. & C.V.\% \\
\hline Tô conmm (mm) & 6.619 & 6.95 & 6.2 & 0.126 & 0.483 & 5.3 \\
\hline Tô conma & 1.406 & 2 & 1 & - & - & - \\
\hline Tô Color & 1 & 1 & 1 & - & - & - \\
\hline Check (Framida) Conma & 2 & 2 & 2 & - & - & - \\
\hline \multicolumn{7}{|c|}{$\begin{array}{c}\text { Maxi }=\text { Highest value; Mini = Lowest value; Tô conmm = Tô consistence in millimeter; } \text { Tô conma = Tô manual consistence; } \\
\text { Tô col = Tô color }\end{array}$} \\
\hline \multicolumn{7}{|c|}{$\begin{array}{l}\text { Table 4. Percentage of testa presence out of } 50 \text { seeds per line after Potassium Hydroxide anc } \\
\text { Bleach test at Sotuba Food Technology Laboratory in 1990-1991 }\end{array}$} \\
\hline \multicolumn{3}{|l|}{ Material } & \multicolumn{3}{|c|}{ Testa percentage (\%) } & \\
\hline \multicolumn{3}{|l|}{ CSM63-original population } & \multicolumn{3}{|c|}{76} & \\
\hline \multicolumn{3}{|c|}{45 field screened lines average } & \multicolumn{2}{|c|}{7.8} & & \\
\hline \multicolumn{3}{|c|}{ CSM63E (CSM63E-18-1AF) } & \multicolumn{2}{|c|}{0} & & \\
\hline \multicolumn{3}{|l|}{ CSM219E } & \multicolumn{2}{|c|}{0} & & \\
\hline \multicolumn{3}{|l|}{ CSM417E } & \multicolumn{2}{|c|}{0} & & \\
\hline \multicolumn{3}{|l|}{ Framida-check } & \multicolumn{2}{|c|}{100} & & \\
\hline
\end{tabular}




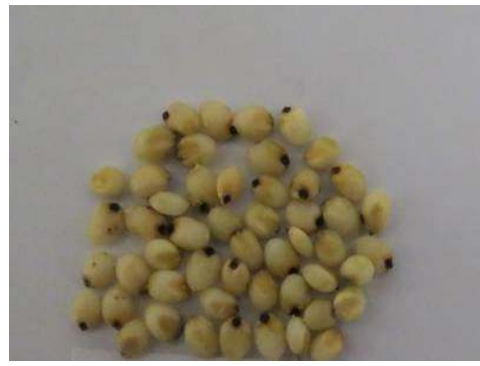

CSM63E

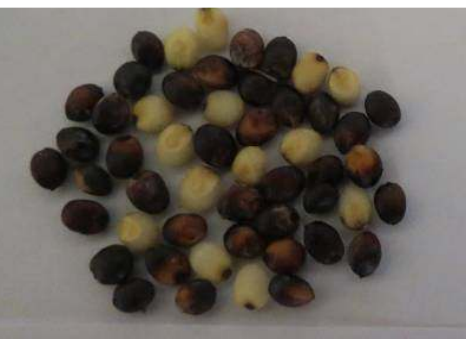

CSM63-Original

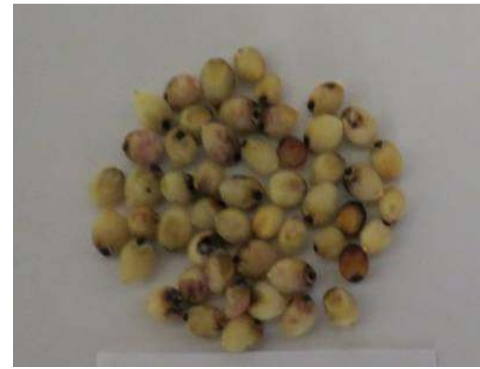

CSM219E

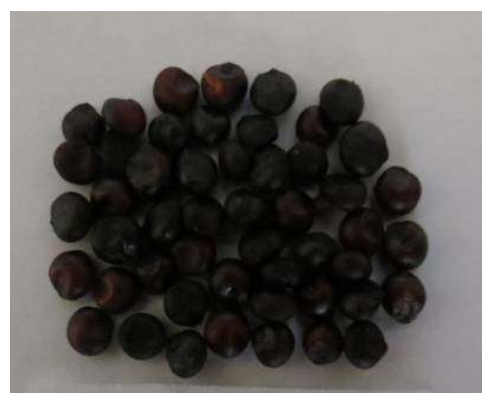

Framida

Fig. 2. Illustration of the effect of Potassium Hydroxide and Bleach Test on sorghum grains. CSM63E has no testa after KOH: B test; CSM63-original shows $76 \%$ testa; CSM 219E (false positive score) and CSM 417E underwent $\mathrm{KOH}$ :B test and show non testa. Framida is a check with $100 \%$ testa. The Testa presence test results were updated using the same $\mathrm{KOH}: \mathrm{B}$ test at Food Technology Laboratory of Sotuba in 2016

\section{DISCUSSION}

Elimination of testa from the original population (CSM63) leading to CSM63E has resulted in a rapid acceptance of the improved cultivar by farmers and housewives subsequent to its improved nutritional values. Tô with dark or red color has no visual attraction and labeled for negative quality for human consumption. By analogy to [9] findings, foods processed from tannin cereals have poor nutritional values. Tannins in the grain impart an astringent taste which affects palatability, reducing food intake and consequently body growth. Tannins bind to both exogenous and endogenous proteins including enzymes of the digestive tract, affecting the utilization and digestibility of protein and carbohydrates, feeding efficiency, metabolizable energy and bioavailability of amino acids [9]. There have been no Tô nutrients composition analysis from this study, but based on findings [9] on non testa sorghum poor food nutrients availability, inference can be made that nutritional values of CSM63 was improved.

False testa presence observed in this present study was reported in previous laboratory tests results [22] who stated that weathered and molded grains effects coupled with anthocyanin migrating deep in the endosperm show false tannin presence. At grains maturity, when insects bite grains and under a high relative humidity, anthocyanin from purple glume penetrates under the pericarp. When $\mathrm{KOH}$ :Bleach test is 
performed, anthocyanin stains pericarp layers and shows false testa presence.

Number of days to $50 \%$ anthesis led to the conclusion that the original CSM63 population was segregating for maturity approximately two weeks apart. Table 1 gives the indication of maturity variability within this population. Segregation in maturity, plant height, glume color in farmer owned variety populations, is observed. Farmers have neighbors who grow different varieties or same with different maturity group which can contaminate each other field and pollute original population traits. Farmer use their next season seed from their previous crop, thus have no control on the genetic integrity of their seed.
Maturity alleles presence are very important when making decisions on which lines to choose where spatial rain distribution is a major limiting factor for good harvest and food security. CMS63E registered and released was not statistically earlier than the original population. Thus agronomic integrity of the original population in term of maturity was preserved.

Good Tô color and nutritional values of CSM63 derived line have been achieved with potential added market value. Author [23] reported that the textural quality of traditional sorghum porridges determines their acceptability to consumers, while [16] claimed that sorghum Tô that is too soft and sticky cannot be molded between the fingers, sticks to the teeth, sticks to the palate

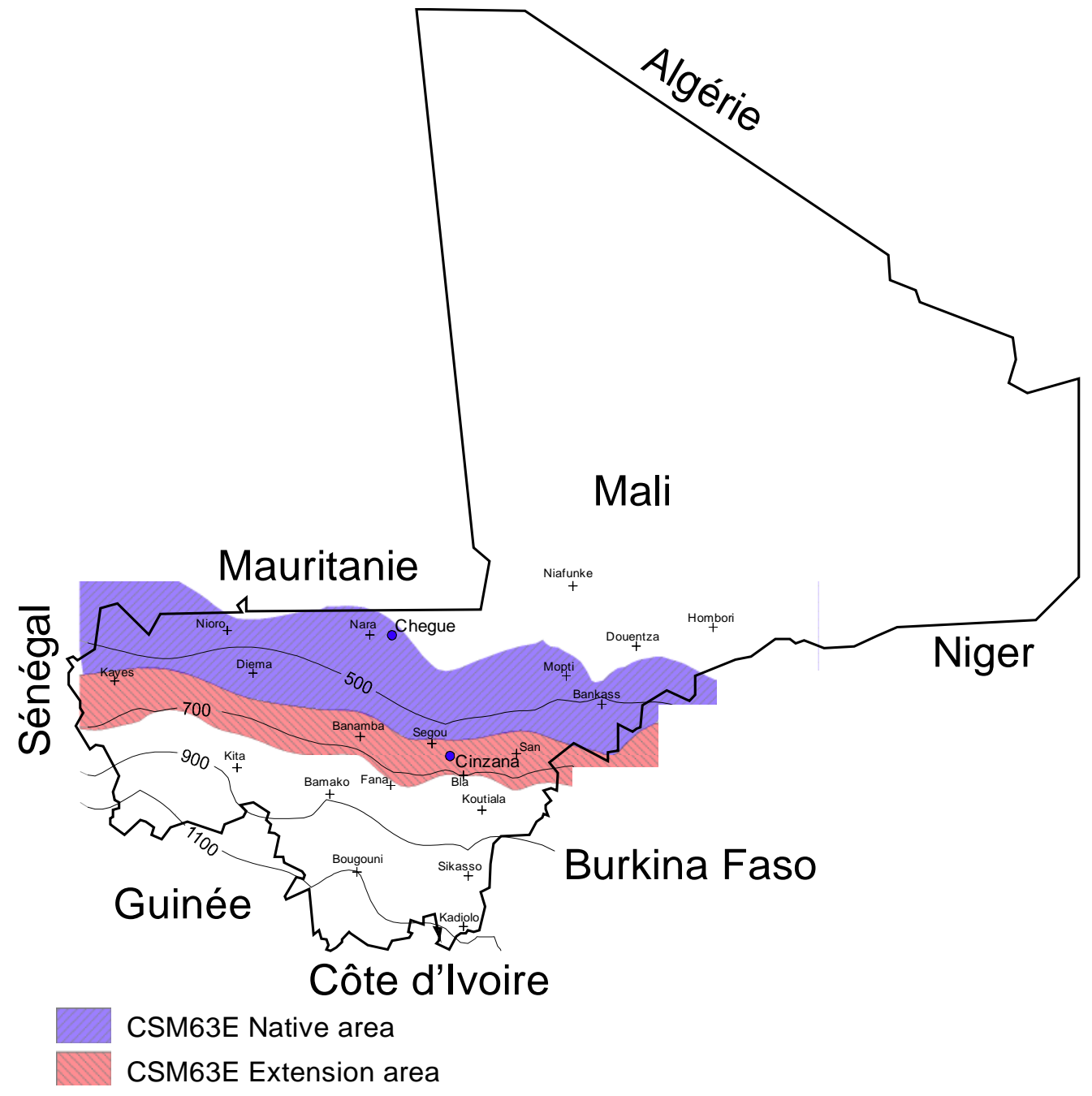

Fig. 3. Illustration of CSM63E adaptation zones of CSM63E drawn from $400 \mathrm{~mm}$ to $700 \mathrm{~mm}$ rainfall, Sotuba 2016. CSM63E cropping zones (Fig. 3) were defined with farmer normal planting periods of each zone using last thirty years rainfall data from the different isohyets 
during consumption, and sticks to the cooking utensils. Consumers prefer sorghum cultivars that consistently produce relatively firm and nonsticky Tô. Data from cooking tests of CSM63E correspond to good Tô criteria [16]. A good Tô has the ability to be a good dinner or breakfast. It is important to notice that original CSM63 had good Tô keeping quality opposed to its poor nutritional value and food attractive appreciation.

Adaptation zone of CSM63E was defined based on different planting periods from $700 \mathrm{~mm}$ to 900 $\mathrm{mm}$ gradients. As this variety originates in Nara, where rain fall is less than $500 \mathrm{~mm}$, it has proven to be very productive in the $600-700 \mathrm{~mm}$ zones where it is very well sold. Beyond this area (600$700 \mathrm{~mm}$ ), CSM63E has shown low yield potential in July planting time in $800-900 \mathrm{~mm}$ of Koutiala and Kafara. Main raisons for its low yield due to late planting are increasing pest damages (crop establishment from damages on seedlings), soil nitrogen depletion after rain onset, seedlings logging. For normal planting period in its area of adaptation, there are no major constraints. While in rainier area $(>700 \mathrm{~mm})$ with early planting, this variety does poorly due to pollen wash from August down pour. Grains are attacked by mold and insect complexes, with anthocyanin leaking into the endosperm, leading to no yield or very poor grain quality. The second most important negative impact is the spread of midges in later varieties. [24] argued that early maturing varieties are not advised where midges (Stenodiplosis sorghicola) attacks on sorghum are serious issue. Authors [24] argued that midge spread occurs from early maturing varieties to late ones, thus resulting in major yield loss for farmers. Beyond $700 \mathrm{~mm}$ rainfall, cropping CSM63E is too risky for farmer. CSM63E, based on its certified seed volume, is well accepted by producers, thus implicitly by consumers. This acceptance is due to its early maturing and food quality, thus alleviating climate variability burden of the very volatile Sahelian environment of Mali.

\section{CONCLUSION}

Combined field screening and laboratory tests were efficient to eliminate testa in a sorghum cultivar in Mali. A pure line, CSM63E-18-1AF (CSM63E), was identified and released. The derived line and its original population are within same early maturity group. Derived line expresses better Tô color and nutritional values and is cropped beyond its center of origin with $400 \mathrm{~mm}$ of rainfall to $700 \mathrm{~mm}$. This pure line has become an alternative solution for farmer to overcome drought and be more resilient. CSM63E is the number one certified sorghum seed produced in Mali in 2016. Cropping zone of CSM63E was defined, beyond which farmers are exposed to poor harvest, grain quality and specially damage due to midge for late maturing sorghum varieties. This variety is grown outside Mali in West Africa Sahelian zone for its earliness and improved processed food qualities, thus overcoming hunger. Strong contribution from extension agents and NGOs are recommended to help farmers to maintain their seed genetic purity. Good agronomic practices and value added products coming from the improved cultivar can contribute to poverty alleviation in rural zones in West Africa.

\section{ACKNOWLEDGEMENTS}

Authors wish to thank farmer who voluntarily gave their seed, colleagues of Cinzana Agronomic Research Station (SARC), the Sotuba Food Technology Laboratory and Sorghum Program. This work was financially supported by IER, INTSORMIL (SMIL) and the Syngenta Foundation for Sustainable Agriculture. We thank late $\mathrm{Dr}$ Darrell $\mathrm{T}$. Rosenow for his technical assistance.

\section{COMPETING INTERESTS}

Authors have declared that no competing interests exist.

\section{REFERENCES}

1. Ministère de l'Agriculture (MA-CPS), Cellule de la Planification et de la Statistique-CPS; 2016.

2. Folkertsma RT, Frederick $H$, Rattunde $W$, Chandra S, Raju GS, Hash CT. The pattern of genetic diversity of Guinea-race Sorghum bicolor (L.) Moench landraces as revealed with SSR markers. Theor Appl Genet. 2005;111:399-409.

3. Aastrup S, Outtrup H, Erdal K. Location of the proanthocyanidins in barley grain. Carlsberg Res. Common. 1984;49:105109.

4. Larkins JR. Location of genes conditioning resistance of barley to leaf rust. Plant Breed. Abstr. 1983;83(10):756 (\#8148). Copyright Cirad 2003 Maxson ED, Clark LE, Rooney LW, Johnson JW. Factors affecting the tannin content of sorghum grain as determined by two methods of 
tannin analysis. Crop Sci. 1972;12:233235.

5. House LR. A guide to sorghum breeding. $2^{\text {nd }}$ ed. Patancheru, A.P. 502324, India: International Crops Research Institute for the Semi-Arid Tropics; 1985.

6. Blakely ME, Rooney LW, Sullins RD, Miller FR. Microscopy of the pericarp and the testa of different genotypes of sorghum. Crop Sci. 1979;19:837-842.

7. Esele JP, Frederiksen RA, Muller FR. The association of genes controlling caryopsis traits with grain mold resistance in sorghm. The American Phytopathological Society. 1993;83:5.

8. Rooney LW, Miller FR. 1982. Variation in the structure and kernel characteristic of sorghum. In: Proc. Int. Symp. Sorghum Grain Quality. L.W.Rooney, D.S. Murty, and J.V. Mertin. Eds. International Crops Research Institute for the Semi-Arid Tropics (ICRISAT): Patancheru, India, October 28-31; 1981.

9. Sorghum and millets in human nutrition. Food and Agriculture Organization of the United Nations, Rome; 1995.

Available:http://www.fao.org/DOCREP/T08 18e/T0818E00.htm\#Contents

10. Available:http://www.fao.org/DOCREP/T08 18e/T0818E0j.htm\#Polyphenols

11. Kofoid KD, Maranville JW, Ross WM. Relationship of the testa to agronomic and nutritional traits in sorghum. Crop Sci. 1982;22:352-357.

12. Hagerman AE, Riedl KM, Jones GA, Sovik KN, Ritchard NT, Hartzfeld PW, Riechel TK. High molecular weight plant polyphenolics (tannins) as biological antioxidants. Journal of Agricultural and Food Chemistry. 1998;46:1887-1892.

13. Riedl KM, Hagerman AE. Tannin-protein complexes as radical scavengers and radical sinks. Journal of Agricultural and Food Chemistry. 2001;49:4917-4923.

14. Bors W, Michel C, Stettmaier K. Electron paramagnetic resonance studies of radical species of proanthocyanidins and gallate esters. Archives of Biochemistry and Biophysics. 2000;374:347-355.
15. Waniska RD, Hugo LF, Rooney LW. Practical methods to determine the presence of tannins in sorghum. Journal Applied Poultry Research. 1992;1:122-128.

16. Washington DC, National Research Council, National Academy of Sciences. Rooney LW, Kirleis AW, Murty DS. Traditional foods from sorghum: Their production evaluation and nutritional value. Adv. Cereal Sci. Technol. 1986;8:317-353.

17. Bello AB, Rooney LW, Vaniska RD. Factors affecting quality of sorghum to, a thick porridge; 1990.

18. Clément J, Marc LB. Prospection des Sorghos en Afrique de l'Ouest : Collecte 1978 : République du Mali. Paris : ORSTOM, 45 p. multigr. (Catalogue ORSTOM); 1980.

19. Kofoid KD, Maranville JW, Ross WM. Use of a bleach test to screen single-head sorghum selections for the presence of a testa layer. Agron. J. 1978;70:775-779.

20. Fall AA, Tall EHO, Kante B, Keita MS. Impact economique de la recherche sur le mil, le sorgho, et le niebe de la Station de Cinzana au Mali. Consultation pour la Fondation Syngenta/Mali \& Suisse; 2003.

21. Laboratoire Central de Certification des Semences, Ministère de l'Agriculture du Mali, Rapport de Certification de Semence, Campagne 2016-2017.

22. Awika J, McDonough CM, Rooney LW, Waniska RD. False Positives for Tannin Sorghum in Non-tannin Sorghum Using the Bleach Test. SAT eJournal/ EJournal. ICRISAT.org. 2005;1:1.

23. Cagampang GB, Griffith JE, Kirleis AW. Modified adhesion test for measuring stickiness of sorghum porridges. Cereal Chem. 1982;59:234.

24. Mamoutou K, Sissoko S, Teme N, Deu M, Vaksmann M, Camara Y, Bazile D, Sako AFM, Sidibé A. Impact de la diffusion d'une variété améliorée de sorgho au Mali: interaction avec les variétés locales/ Dissemination impact of a sorghum improved variety in Mali: Interaction with landraces. Agronomie Environnement et Société. 2014;4:2.

(C) 2017 Niaba et al.; This is an Open Access article distributed under the terms of the Creative Commons Attribution License (http://creativecommons.org/licenses/by/4.0), which permits unrestricted use, distribution, and reproduction in any medium, provided the original work is properly cited.

Peer-review history:

The peer review history for this paper can be accessed here: http://sciencedomain.org/review-history/20280 